Марина Милошевић

Универзитет у Београду

Филолошки факултет
$316.77(44)$

https://doi.org/10.18485/melissa.2017.16.1.ch21

\title{
МЕДИЈСКО ОБРАЗОВАЊЕ У ФРАНЦУСКОЈ
}

\section{Сажетак}

Термин медијско образовање се обично повезује са способношћу анализирања и евалуације медијских порука, као и способношћу да се комуницира на разне начине. Постоје велика очекивања у вези са наставним програмима за медијско образовање које се може схватити као процес који траје читавог живота. Већина нас прихвата оно што нам масовни медији нуде, па тако несвесно добијамо информације о томе ко је, и шта важно у нашем животу. Данас је очигледна све већа присутност медија, те су они саставни део друштва.

Овај рад показује колико је важна заједничка улога медија и институција образовања у процесу описмењавања друштва, на примеру Француске. Французи сматрају да деца у школама треба најпре да се оспособе за рад, али и да стекну способност критичког размишљања и самосталног ишчитавања информација које су нам доступне од стране медија.

Кључне речи: медији, образовање, друштво, школа, Француска

\section{Уводне напомене}

Израз медији, све до почетка прошлог века, практично није ни постојао. У то време се полако рађала индустрија оглашавања, тежња да се промене постојећи ставови, мишљења, као и потреба да се утиче на формирање јавног мњења. Првобитни медији - новине и часописи имали су заједничко име. Временом се јављају нова средства масовне комуникације, те се израз штампа замењује изразом медији, а данас се под овим изразом подразумевају и најновија средства масовне комуникације, попут интернета.

Проучавање медија и образовања базира се на анализи целокупног друштва. Нова сазнања која се појављују у медијима, у великој 
мери мењају понашање деце и родитеља у односу на претходне генерације. Тешко је наћи праву дефиницију медија, али чињеница је да крајњи циљ медија, подразумева комуникацију. Од латинског medium, „средина“, „центар“ (medium diei, „средина дана“), па преко значења, „посредника“, „медијатора“ (paci medium se offert, „нуди се да буде посредник мира“, Вергилије), долазимо до поновног открића термина од стране Англосаксонаца, који су увели појам „масмедија“, као средства за комуникацију маса. (Гоне 1998: 14)

Масовна употреба нових медија у образовне сврхе је неопходна, јер се подразумева да ће нови медији са собом донети знање и утицати на становништво. Да ли ће тај утицај бити позитиван или негативан, умногоме зависи од школе чији је крајњи циљ - пренос знања. Често се под термином образовање, подразумева васпитање. Чињеница је да школа не може једноставно васпитати, а да истовремено и не образује. Образовање (латинска реч ducere водитu) подразумева постојање водича, едукатора којем је поверено васпитање. Филип Мерије бележи следеће: Образовање је једна необична делатност, увек се понашамо као да само едукатор својом делатношћу утиче на развој едукованог, и као да ни најмањи узрочно последични однос не може бити успостављен и у супротном смеру. То, уосталом значи да се образовање једне личности поистовећује са производњом једног предмета. Такав став пориче смисао самог чина образовања. (Мерије 2004: 187)

\section{Медијско образовање}

Медији нас увек враћају на нас саме, пажњу коју ћемо посветити једној информацији, зависи од нашег личног и друштвеног односа према њој. Кроз овај рад, бавићемо се садејством образовања и медија у Француској.

Данас се све више говори о медијском образовању, медијској култури, педагогији, дидактици, етици, критици медија, итд. Појава медија у свим подручјима живота имплицира и медије у образовном процесу. Нужно је међутим, сада више него икада у наставу увести 
нове медије и технологије с којима су деца свакодневно окружена. Дошло је време да се ученицима омогући критичко и конструктивно посматрање медија, да се у образовном процесу медији користе функционално и смислено. Ученике треба заинтересовати за образовање путем медија, али им и омогућити сналажење у богатом медијском свету, препуном информација.

Лин Мастерман наводи седам суштинских разлога за неопходност медијског образовања:

1. висока потрошња медија и презасићеност до које стижемо;

2. идеолошки значај медија, посебно имајући у виду рекламе;

3. појава информационог руковођења у предузећима (политичке партије, министарства, итд.)

4. нарастајући продор медија у демократским процесима (избори су, пре свега, медијски догађаји)

5. нарастајући значај визуелне и информационе комуникације у свим доменима (изузев школе, која првенство даје штампаној грађи; комуникациони системи су углавном визуелног карактера)

6. очекивања младих да буду образовани тако да могу да разумеју своје доба (какав је смисао образовања и изградње индивидуалне културе, ако се тако брижно избегавају технолошка средства и преиспитивања вредности свог доба);

7. национални и међународни пораст приватизације свих информационих технологија (када информација постане производ, њена улога и њене особине се мењају). (Гоне 1998: 14)

\section{Институције задужене за легитимитет знања}

Образовне установе учествују у процесу легитимизације знања, та тела осмишљавају, прате и координирају развој образовања и обуке, али и интересе и потребе свих социјалних партнера. Могуће је разликовати два типа организација, међународне организације и образовне структуре при појединим националним министарствима образовања. 
Почетни рад, који су већ од оснивања, од 1945. до 1950. године, покренуле међународне организације попут Унеска и Европског савета, утолико је оправданији што се по многим својим карактеристикама уклапа у саму мисију ових организација. (Гоне 1998: 46-47) Унеско има за циљ да допринесе успостављању мира путем сарадње међу народима, зближавањем њихових образовних система, наука, култура и комуникација, те отуда и размишљање о медијима налази своје место у програмима посвећеним „описмењавању“. Захваљујући овим циљевима, 1982. године донета је Декларација о обавезном медијском и информационом образовању од предшколског до универзитетског нивоа, коју су прихватиле многе европске земље.

Међутим, у земљама у којима медијска и информациона писменост још увек нису укључене у наставне програме, ово образовање се спроводи кроз врсте неформалног образовања у којима кључну улогу имају библиотекари. У Француској се посебно истиче улога документалисте који користи информације добијене путем медија, и ставља их на располагање ученицима, како би их заинтересовао, и помогао да боље схвате чињенице, догађаје и проблеме. Документалиста-библиотекар је одговоран за изградњу центра документационих и мултимедијских извора. (Гоне 1998: 76)

Када говоримо о министарствима, ту је сасвим другачија логика. То је логика власти с једне стране, док је с друге стране и педагошка логика која је много делотворнија у организацији установа и правилима функционисања, него у иновирању. Ипак постоје и оне организације које се искључиво баве образовним циљевима. У оквиру ове теме, издвојићу следеће институције:

- Школска радио-телевизија. У Француској, овај сервис је најчешће деловао у форми „педагошких радионица“ за предаваче. Назив овог предузећа се кроз историју често мењао, данас делује као Национални центар за педагошку документацију ${ }^{1}$. Овај центар има право да на државним телевизијским каналима промовише образовање, које је у складу са општим правилима о учењу, сазнању и забави.

- Регионални центри за педагошку документацијуㄹ, створили

1 CNDP - Centre national de documentation pédagogique

2 CRDP - Centres regionaux de documentation pédagogique 
су мрежу, која је често била одлучујући фактор у промени навика и обичаја ученика. У Регионалном чентру у Клермон-Ферану, спроведена је акција под називом Француска лицем према будућности, која је комбиновала регионалну телевизију, радио и штампу, са пропратним документима, како би ученици научили да структуришу своје знање. Следећу акцију финансирало је више министарстава, акција је позната под називом Млади активни телевизијски гледалац (1975. године), и имала је за циљ да различите учеснике наведе на размишљања о начину на који деца прихватају телевизијске емисије.

- Године 1982. израђен је пројекат, а затим је Министарство националног образовања оформило Центар за односе образовања и средстава инфоромисања (CLEMI). (Гоне 1998: 48). Овом чентру поверена је мисија „промовисања путем специјалних образовних акција, разноврсних начина коришћења средстава информисања, са циљем да се ученицима помогне да боље разумеју свет који их окружује и да се допринесе развоју њиховог критичког мишљења." Центар делује у оквиру Министарства националног образовања и његова мисија јесте организачија медијског образовања у Француској. Од 1990. године сваке године, током прве недеље априла, одржава се Недеља штампе у школи. Руководилац ове акције јесте CLEMI, а циљ је упознавање ученика са важношћу штампе у стицању основних знања, али и у стицању грађанског идентитета. Године 1996. акција је постигла велики успех, када је у њој учествовало више од 3 милиона ученика, иако је била необавезна. У почетку замишљена да допринесе учесталијој примени писане штампе у школама, ова акција је еволуирала и узела у разматрање све врсте медија. Акција нема комерцијалну основу, она заправо почива на доброј вољи и иницијативи сваког појединачног учесника.

Мотивисање деце да уче уз медије, представља задатак друштва и институција, али наставника и родитеља, који заједно треба да одлуче како да се на прави начин искористи образовни потенцијал свих врста медија.

3 CLEMI - Centre de liaison de l'enseignement et des médias d'information

4 Министарско решење од 26. априла 1983. године, потврђено Декретом од 25. марта 1993. године 


\section{Положај школског уџбеника - могућност коришћење новина у настави}

Уџбеник је често представљен као слика самог легитимитета знања. Многа истраживања доказују да је мотивисаност деце одлучујући фактор процеса учења. Зашто на пример, не би било могуће да се читање учи и уз штампу? Штампом се подстиче осећај радозналости, затим доноси велики број практичних вежби које су испуњене забавним елементима.

На крају прошлог века, издавачка кућа Larus је заједно са наставницима сачинила један педагошки програм за учење историје и географије уз помоћ актуелних фотографија из штампе. (Гоне 1998: 44) Многа стручна новинарска удружења полако су почела да се занимају за то, те се, на пример још давне 1971. године у седишту новина Ouest-France, водила жустра дискусија на ову тему. Дискусији су присуствовали представници Удружења универзитетских новинара $^{5}$ и Удружења младих за штампу и информације.

У брошурама Радне библиотеке ${ }^{7}$ која представља збирку текстова за увођење у знање и помоћ деци, постављају се сва питања која одговарају овој теми. Колекција је креирана 1932. године од стране Селестина Френеа (Célestin Freinet, 1896-1966), који је купио штампарију, те је штампао бесплатне текстове за ђаке. Ученици су састављали своје радове, дискутовали о текстовима, уређивали их, а онда их представљали као резултат тимског рада. Постепено су групни текстови заменили конвенционалне школске књиге. Његова жеља била је да се изгради права енциклопедија школа, која ће донесити најразличитије информације. Занимљиво је то да је, 1926. године био оптужен у часопису L'Éclaireur de Nice, да деци улива осећај бесмртности, јер штампају своје текстове. Његови наставни методи били су у супротности са званичном политиком Националног одбора за образовање, те је дао оставку 1935. године, а онда и отворио своју школу у Вансу.

\footnotetext{
$5 \quad$ AJU - I'Association des Journalistes Universitaries

6 APIJ - I'Association presse information jeunesse

7 La bibliothèque de travail (BT)
} 
Пример коришћења новина у настави, јавља се и у Америци, када је директор јавних школа у Салему, држава Мисури, сматрао себе заступником коришћења новина, те је од 1884. године, ово спроводио и у пракси. Био је претплаћен на 60 новина које је делио по разредима, а онда од ученика захтевао да испричају шта су прочитали.

Данас, многи стручњаци истичу да би медији у образовним системима требало да представљају засебну научну дисциплину због широког спектра њиховог деловања.

Дакле, који би смисао данас могла имати појава једне нове дисциплине усредсређене на медије? Какви би били њени садржаји? Тезу о хитности поставили су најпре покретачи ове идеје у Француској, као и у иностранству. Суштина хитности је у томе да се не дозволи да наша свакодневница буде преплављена медијима, који све више одређују наше представе и свакодневне рефлексе, а да се школа уопште не укључује предлозима о критичкој дистанци. (Гоне 1998: 55)

Програми медијског образовања - француски пример

Различити програми медијског образовања подвлаче чињеницу да су медији у свим срединама значајни и за школство. Обавеза школе је да ученика научи да буде активни гледалац, независни истраживач и истински учесник медијске комуникације.

Медији утемељују стварност, обавештавајући нас о свету, заправо представљају различите начине његовог опажања и његовог схватања.

Програми медијског образовања препоручују да се од пете године старости детета, започне рад са медијима. Тада почиње социјализација, која се првобитно остварује у предшколским установама. Игра има значајну улогу у развоју и учењу предшколског детета. Деца тог узраста су изразито креативна, те често своје идеје исказују цртежима и другим маштовитим производима. Способност за супростављање свога мишљења мишљењу других, јавља се од осме године. Од осме па све до дванаесте године, дете се постепено укључује у друштво. Током овог периода дете открива различите врсте говора, опонаша одрасле, па чак и покушава да превазиђе то опонашање. Већ око дванаесте године, дете проживљава једно ново искуство у вези са променама које се у школи дешавају. До суш- 
тинских промена у односу младих према свету, долази се негде око петнаесте године. Они формирају такозване групе пријатеља истог узраста, и већ тада постају изразито осетљиви на слику света коју доносе медији. На крају доба адолесценције, млади испољавају презир или одушевљење према неким глобалним пројектима, осећају да их грађанске институције још увек одржавају на инфантилном ступњу, а да су они спремни да се укључе у друштвени положај, и да делују као одрасли. Ова потреба наводи младе да све више учествују у решавању проблема савременог живота. Другачије речено, размишљање о медијском образовању полако прелази у размишљање о перманентном образовању.

Према речима Мишела Пишета, истраживача на Универзитету Квебек у Монтреалу, у школским програмима медијско образовање треба и може да покрије целокупну наставу. Све дисциплине поседују погодности да се кроз њих обраде и медији, слично као што све оне већ одавно поседују и погодности да се кроз њих развија владање матерњим језиком. Од наставе математике до студија географије, екологије, историје или матерњег језика - све дисциплине могу да допринесу медијском описмењавању. (1995: 126)

У Француском образовном систему, важе нешто другачија правила. Предшколске установе су обданишта (l'école maternelle). Постоји и основна школа (l'école primaire, l'école éleméntarie), потом нижа средња школа- колеџ или колеж (le coèllge), који траје само четири године (разреди су класирани обрнутим смером - постоје шести, пети, четврти и трећи разред), затим виша средња школа - гимназија (le lycée), или средње стручне школе (le lycée professionnel), које такође трају по четири године. На крају долази полагање матуре (le baccalauréat), после које следе студије на универзитетима и високим школама.

У обданишту, дете учи да живи у групи, комуницира и гради првобитну основу сопственог грађанског образовања. Деца свакодневно слушају текстове из усмене традиције, попут песама, бројалица, бајки, загонетки, и сл. Ови текстови су најчешће праћени сликом и звуком, те тако успевају да привику пажњу и у великој мери заокупирају дечје мисли. Дете се постепено уводи и у свет писма, писањем одређених кратких писмених радова који у себи могу да сад- 
рже и слику и текст (албуми, илустроване приче, и сл.). Да би развило своју интелигенцију, полако се уводи и у свет слика, које могу бити:

- фиксне слике (фотографије, албуми, плакати, и сл.)

- оживљене слике (видео, телевизија, филм, и сл.)

Не треба заборавити да у том узрасту, изразита креативна слобода, може бити повод за свакојаке врсте стваралачких производа.

Крајњи циљ већини школа је да ђаке подучи одређеним способностима, знању и вредностима, које су извучене у званичном опису предмета. Школа првенствено подучава вербалном изражавању - у говорном, писаном и штампаном облику. Телевизија се базира на аудиовизуелном језику, и она се јавља као веома битан фактор приликом учења страног језика. На основу различитих истраживачких радова, може се доћи до закључка да је језик могуће научити посматрањем вербалних интеракција других особа. Телевизија нам пружа обиље таквих интеракција које се одвијају у најразличитијим друштвеним ситуацијама, уобичајене су, понављају се, те их дете лако усваја.

За основно образовање, поменућемо метод учења помоћу слика, а оно што треба истаћи, то је пример Библиотечко-документационог центра ${ }^{8}$ чије је истраживање о коришћењу слике као методе за увођење детета у анализу смисла, настало поређењем смисла које дете придаје одређеној слици са осталим могућим виђењима те слике. Да би се ученици упознали са различитим програмима, препоручују се штампа, рачунари, речници, едукативне игре, као и разноврсна приручна помагала. Треба неговати писмено стваралаштво код деце, те се препоручује израда школских новина, као један облик слободе изражавања и информисања.

Програми за колеџе - средње школе првог степена, препоручују постављање ученика у разноврсне комуникационе ситуације, током којих ученик почиње да схвата и основне појмове комуникације (порука, пошиљалац, прималац, различити језички контексти, итд.). Студирање слике је и овде унето у програм, али и редакција школских новина, реализација кратких реклама, и др. Ученици се оспособљавају за анлизу ситуација у свакодневном животу, и то покретањем стечених знања. Уводе се у основна знања из области истраживања, анкетирања и селекције информација.

$8 B C D$ - la Bibliothèque centre de documentaire 
У гимназијама, сви програми предлажу продубљивање знања стечених у нижој средњој школи (колеџ). Програми за средњошколско образовање се разликију од профила и области којом се одређена школа бави. Општи циљеви су везани за медији у односу са другим дисциплинама, посебно на примеру студија слике и схватању везе између слике и текста, изучавању и сагледавању правилног говорења кроз различите видове вежби, чиме се ученицима омогућава да стекну способност за креирање сопственог мишљења. Предлаже се на пример успорена пројекција од неколико минута одређеног биоскопског или телевизијског филма, или пак анализа шпице, затим оснивање редакција школских новина, рад на штампи, итд. Као методе користе се и разноврсне анкете и испитивање јавног мњења. За учење језика, даје се предност аудио-визуелном образовању, телевизији, филмовима на француском језику или страном језику, и др.

Наставник је медијатор у процесу анализе медијских текстова и усмерава ученике да разликују, дефинишу, упоређују, анализирају и откривају, те да стечена знања користе у процесу креативне производње сопствених медијских текстова. Добра подучавања долазе од добрих наставника. Најбољи наставници траже сталне могућности за истраживање нових метода и проширење стратегија за ангажовање ученика у сопственом учењу. Наставници развијају своје вештине постајући сами доживотни ученици. Медијско образовање може послужити као образац за нов начин учења и осталих предмета, корелације медијске писмености су најинтензивније када су у питању језик и књижевност, психологија, социологија, уметности, потом историја, али и осталих предмети.

У XXI веку ученици долазе са вештинама, информацијама и претходним знањем које није било доступно ранијим генерацијама. Припрема наставника за рад са ученицима који проводе хиљаде сати испред телевизијских екрана, користе социјалне медије, затим познају десетине видео игрица које су савладали још пре обданишта, а онда и постали мајстори паметних телефона, представља огроман изазов наставницима медијског образовања. Неколико студија је показало да су адолесценти активни и самопоуздани корисници медија, али да они такође показују значајну наивност у погледу социјалних и политичких структура и позадина. Ученици треба да стекну јасну слику о свету, како 
би били способни да из мноштва информација и нових чињеница које медији свакодневно доносе, издвоје оно што је важно.

Када говоримо о месту медија у образовању, чим се пређе са школског на универзитетски ниво, јављају се нова питања. Увођење једног новог наставног предмета који укључује медије, још увек је у фази континуираног развоја. Науке о информацији и комуникацији, уско су повезане и основане у склопу друштвених и хуманистичких наука, проистекле из тежње да се пронађе место дисциплини, која би била спремна да се избори са текућим променама у друштву и тзв. поплавом информација.

Дејвид Гонтлет, стручњак за медије, сматра да студенти треба да анализирају медијску културу, тако што ће нешто да направе уместо да само пишу есеје и дају исказе о свакидашњим аспектима медија. На тај начин, студије медија ће бити у бољој позицији да помогну друштву и повежу медијску креативност са стварањем идентитета који омогућава интеракцију са светом. На академском нивоу примећујемо наклоност и жељу наставника за образовањем у погледу нових области, чије је тумачење сваким даном важније и неопходније. Захтев за оваквом врстом образовања повећава се из године у годину. У Француској, ова тематика се врло озбиљно истражује како на Универзитетским институтима за образовање наставника (IUFM) ${ }^{9}$, тако и на Академским посланствима за образовање кадра за национално образовање $(M A F P E N)^{10}$, нарочито у форми курсева и дужих студија.

\section{Закључне напомене}

Како је за успех неопходно доживотно учење, концепт образовања током целог живота је један од кључних фактора за XXI век. Медије не треба само критиковати, треба их чувати и развијати, то је једно више очекивање, које подразумева већи значај медија од обичних средстава за комуникацију. Школа и медији треба да се познају и да удружени учествују у пројекту који ће бити важан за целокупно друштво. Образовни рад са медијима мења традици- 
оналну поделу улога, ученици постају активни субјекти у преносу информација и стицању знања. Медији су истински извор знања, а проучавање медија је заправо наставак темељних знања.

Долази се до напретка на пољу образовања, те класично уверавање губи корак због све боље обавештености јавности. Да би се носили са манипулацијом медија, потребно је код грађана створити свест да је њихова обавеза да судбину не препуштају другима, као и да се оспособљавају за дешифровање јавних порука.

Важно је да се у образовном систему, не стичу само знања и вештине, већ и одгајају карактери. Француски образовни систем у себи садржи и подучавања о разумевању, дешифровању и критичком односу према порукама које се налазе свуда око нас, а наметнуте су нам од стране медија.

Медији су сматрани узроком проблема, како у друштву, тако и код деце, док се медијско образовање сматра решењем за те проблеме. Од наставника се очекује да подучи ученике способностима да се критички односе према медијима, што ће им помоћи у процесу сазревања и стварања карактера. Медијско образовање имаће далекосежне утицаје на дефинисање школства, демократије, а онда и на наше поимање знања у целости.

\section{Литература}

Lobro, Mišel. Obrazovanje pre svega. Prevela Mirjana Vukmirović. Beograd: Izdavačkografički zavod, 1979.

Pichette, Michel. „Apprendre à vivre avec les médias, une urgence pour l'école et la démocratie“. L'école et les médias, (1995): 126.

Bal, Fransis. Moć medija: mandarin i trgovac. Prevod Izabela Nikodijević. Beograd: Clio, 1997. Gone, Žak. Obrazovanje i mediji. Prevod Vesna Injac-Malbaša. Beograd: Clio, 1998.

Prajs, Stjuart. Izučavanje medija. Prevod Vladimir Kolović. Beograd: Clio, 1998.

Debre, Režis. Uvod u mediologiju. Prevod Marijana Ivanović. Beograd: Clio, 2000.

Миленковић, Слађана. Медији и образовање. Рума: Графампромет, 2008.

Вујовић, Ана. Савремена француска култура : неки аспекти. Београд: Учитељски факултет, 2008.

Martinoli, Ana. „Novi mediji i kreativne industrije - nove mogućnosti za publiku.“ Kultura br. 128 (2010): 161-86. 
Poter, Džejms. Medijska pismenost. Prevod Đorđe Petrović. Beograd: Clio : FORIN [i.e.] Fond za razvoj istraživačkog novinarstva i novih medija, 2011.

Јанићијевић, Јасна. „Медији и публика.“ Годишњак Факултета за културу и медuje, бр. 3 (2011): 147-64.

Baran, Stanley J. Introduction to mass communication : media literacy and culture. New York: McGraw-Hill Companies, 2012.

Мерије, Филип. Образовање је васпитање : етика и педагогија. Превод Бранислава Гонтје Пешић. Београд: Завод за уџбенике, 2014.

Burdije, Pjer i Žan-Klod Paseron. Reprodukcija: elementi za jednu teoriju obrazovnog sistema. Prevod Slavica Miletić. Beograd: Fabrika knjiga, 2014.

https://www.expatica.com/fr/education/Education-in-France_101147.html (04.01.2018.)

https://about-france.com/primary-secondary-schools.htm (04.01.2018.)

https://www.clemi.fr/ (04.01.2018.)

\title{
Marina Milošević \\ University of Belgrade \\ Faculty of Philology
}

\section{MEDIA EDUCATION IN FRANCE}

\begin{abstract}
Summary
The term media education is usually associated with the ability to analyze and evaluate media messages, as well as with the ability to communicate in various ways. There are high expectations in relation to the curriculum for media education that can be understood as a lifelong process. Most of us accept what the mass media offer us, so we unconsciously receive information about who is and what is important in our life. Today, there is an increasing presence of the media, and they are an structural part of modern society.

This paper shows the importance of the common role of the media and educational institutions in the literacy process of the society, on the example of France. The French consider that children in schools need to be trained for work, but also to gain the ability to critically reflect and an independent understanding of information that is available to us by the media.
\end{abstract}

Key words: media, education, society, school, France 